\title{
Literatur
}

EWUng = Etymologisches Wörterbuch des Ungarischen 1-3. Hrsg. Loránd Benkő. Akadémiai Kiadó. Budapest 1993-1997.

MSzFE = A magyar szókészlet finnugor elemei I-IV. Hrsg. György Lakó. Akadémiai Kiadó. Budapest 1967-1981.

RónA-TAS, ANDrás \& ÁrpÁd Berta: West Old Turkic. Turkic loanwords in Hungarian. Part 1: Introduction, Lexicon: "A-K". Turcologica 84. Harrassowitz Verlag. Wiesbaden 2011.
RónA-TAs, András \& ÁrpÁD Berta: West Old Turkic. Turkic loanwords in Hungarian. Part 2: " $L-Z$ ". Conclusions, Apparatus. Turcologica 84. Harrassowitz Verlag. Wiesbaden 2011. TESz = A magyar nyelv történeti-etimológiai szótára 1-4. Hrsg. Loránd Benkő. Akadémiai Kiadó. Budapest 19671984.

UEW = Uralisches etymologisches Wörterbuch I-III. Hrsg. Károly Rédei. Akadémiai Kiadó - Otto Harrassowitz. Budapest - Wiesbaden 1988.

\section{Detachment constructions in European languages and beyond}

\section{<https://doi.org// 0.33339/fuf.79543>}

M. M. Jocelyne FernandeZ-Vest: Detachments for Cohesion. Toward an Information Grammar of Oral Languages. Empirical Approaches to Language Typology 56. De Gruyter Mouton 2015. XVII + 290 pp.

The book, as its title illustrates, examines Detachment Constructions in oral languages from various perspectives. The term oral languages includes both strictly oral languages without a written tradition and the spoken variants of written languages. The use of Detachment Constructions is presented in several different discourse styles crosslinguistically, comparing European languages belonging to the IndoEuropean and the Finno-Ugric groups, and also considering other languages briefly.

Dislocated NPs either in front or at the end of utterances are traditionally referred to as detachments (or dislocations). Detachment Constructions are used mainly in spoken languages as a device for information structuring. They usually mark the topic when it is inactive in the hearer's consciousness. (Lambrecht 1994, 181-184.)

The author distinguishes Initial and Final Detachments and introduces previous research to exemplify their different functions. Initial Detachments usually share 
common reference with the Theme and are used to introduce new topics. Final Detachments, on the other hand, often share common reference with the Rheme or other elements in the shared knowledge, and they function as Mnemes and ensure cohesion in the discourse. Moreover, Initial and Final Detachments diverge morphosyntactically as well: on Final detachments, the grammatical function is marked, whereas Initial Detachments are left without marking as a rule. Furthermore, Detachments can have different roles depending on context. This is demonstrated with the analysis of argumentations: in monological argumentation, detachments can be used for convincing, while in dialogical reasoning, they can have a highlighting function.

Orality and the features of oral languages are one of the central issues of the book. The relationship of oral and written language has been inadequately investigated so far. The author fills this gap with the comparison of different text types in their written and spoken form. Detachments, as is expected, are found more often in the spoken register than in the written form. However, the type of discourse also influences their occurrence. Apart from the Information Structuring devices of oral languages, their structure - which relies mostly on prosody
- and their constituent order also differ from that of written texts. Additionally, there are language specific differences between spoken and written registers: the analytic constructions of spoken Finnish, for example, are often replaced with NonFinite Constructions in writing.

The author also ventures to study how Detachments are delivered in oral translation. This task is challenging due to the lack of appropriate material. Thus, the author resolves to compare theater lines and translations of comics in Finno-Ugric and Indo-European languages, also considering Asian languages briefly. The texts for comparison were chosen carefully, with special attention paid to their oral features. The theatre lines in comparison provide evidence of the differences in Information Structuring between French, Finnish and Estonian. The comic translations show how different languages accept the use of detachments. Initial Detachments are used in all of the languages, while the delivery of Final Detachments is usually more problematic. The translations of the comics in some of the topicprominent Asian languages, which consider the notion of topic more central than the notion of subject (Li and Thompson, 1976, 459-461), show that detachment constructions are used in a wide variety of 
languages. The comic translations also provide evidence that detachments may show different behavior even in closely related languages. All in all, it seems fruitful to investigate detachments and other information structuring devices crosslinguistically in further detail.

Detachments are usually combined with other Information Structuring devices in spoken languages. Among these, the book introduces Discourse Particles and intonation in more detail. Discourse Particles are used widely in colloquial Finnish, but their use is excluded from official and planned discourses. The comparison of oral and written Finnish proves that Discourse Particles play a crucial role in the Information Structuring of the spoken register, and their absence in the written register changes the communicative impact of the text. The use of Discourse Particles is further investigated in the other Finnic languages. For this purpose, the author has chosen to compare proverbs, which emerge from the oral tradition. Discourse Particles are used in the Finnish proverbs more often than in the other Baltic-Finnic, Scandinavian and Germanic ones. Discourse Particles provide cohesion in these utterances and emphasize the rhythmic dimension of oral syntax. The influence of prosody on Information Structure has already been pointed out by Lambrecht (1994, 225), for example. FernandezVest brings forth more evidence on this matter from Indo-European languages and also exemplifies it with previous research on Mandarin Chinese, in which tones, stress and intonation all exist and all have different functions.

Detachments in change, under the influence of language contact situations and grammaticalizations, are introduced only briefly in the book. This issue has been especially poorly investigated so far and needs to be researched further. The author exemplifies the possible outcomes of language contacts on Information Structuring with Swedish-Finnish and Californian Finnish. SwedishFinnish serves as a good example on the change of Mnemes: as Swedish lacks a case system as extensive as that of Finnish, native Swedish speakers do not necessarily mark grammatical roles on Mnemes when they speak Finnish. The case of Californian Finnish, on the other hand, shows that speakers use different strategies in Information Structuring than those used by standard English and Finnish speakers. For example, a large variety of accent variants are used in their Finnish speech, which is atypical in standard Finnish. Unfortunately, this chapter in the book is rather short, probably due to the lack of material available. 
The influence of standardization on the Northern Saami Detachment Constructions, is, however, better elaborated. The Northern Saami data analyzed in the book was collected at the time of creating the written standard for the language. The influence of neighboring languages on spoken Saami is visible: as an example, the Discourse Particles that are used by the older generation are replaced by adverbs of emphasis or cleft constructions, which are used in the Scandinavian languages for Information Structuring. Detachment Constructions, on the other hand, are better preserved, Initial Detachments especially. Final Detachments are used to some degree in written Saami as well, which may be supported by their use in colloquial Finnish. However, as their use is limited in other registers of Finnish and they are excluded from the Scandinavian languages, they may fall out of use.

There are some inconsistencies concerning example sentences throughout the book. In the analysis of Example (5) on page 13, the author refers to lines that are not included in the example and cannot be accessed in any way as they are from a private archive. Furthermore, in some examples, the translation may contain inaccuracies, but the example sentences are still understandable even without knowledge of the original languages.
The inconsistencies in the numbering of example sentences make it difficult to search for examples mentioned in other parts of the book. On page 59, for instance, the author refers to Saami answers and advises the reader to look for them in Example (44). This, however, is a French example sentence. Such irregularities occur several times in the book, but in most of the cases the relevant examples are repeated.

In conclusion, the book provides a good overview of the characteristics of detachments crosslinguistically and takes initiative towards the establishment of information grammar of oral and spoken languages. Many of the issues discussed in the book have been inadequately researched so far, and the author has managed to show a possible way towards their more profound investigation.

\section{Mariann Bernhardt}

\section{Literature}

LAmbrecht, KNUD 1994: Information structure and sentence form: Topic, focus and the mental representations of discourse referents. Cambridge Studies in Linguistics 71.

Li, Charles L. \& Sandra A. Thompson 1976: Subject and Topic: A New Typology of Language. - Charles L. Li (ed.), Subject and Topic. New York: Academic Press, Inc. 